\title{
Requirement of CD4-positive T Cells for Cellular Recruitment to the Lungs of Mice in Response to a Particulate Intratracheal Antigen
}

\author{
Jeffrey L. Curtis, ${ }^{\star * \$}$ Patricia K. Byrd, ${ }^{\star *}$ Martha L. Warnock," and H. Benfer Kaltreider** \\ Respiratory Care Section, Medical Service, San Francisco Veterans Administration Medical Center, ${ }^{*}$ and Departments of Medicine ${ }^{*}$ \\ and Pathology," and Cardiovascular Research Institute, "University of California, San Francisco, California 94121-1598
}

\begin{abstract}
To determine whether CD4+ $\mathrm{T}$ cells participate in the recruitment of other lymphocyte subsets to the lungs, we examined pulmonary immune responses in C57BL/6 mice treated in vivo with the MAb GK1.5, either intact (which depletes CD4+ cells) or as $F\left(a^{\prime}\right)_{2}$ fragments (which block CD4 molecules). After intratracheal challenge with sheep erythrocytes, antigenprimed mice treated with intact GK1.5 had marked decreases in lymphocytes and macrophages in bronchoalveolar lavage fluid and minimal parenchymal inflammation, compared to primed mice treated with an isotype-matched irrelevant antibody or with no antibody. At $7 \mathrm{~d}$ after challenge, flow cytometric analysis showed that numbers of Thy $1.2+$ and $\mathrm{B} 220+$ cells, but not of CD8 + cells, were markedly decreased in lavage fluid of CD4-depleted mice. Similar suppression of the pulmonary immune response to intratracheal challenge was found in primed mice injected repeatedly with $F\left(a^{\prime}\right)_{2}$ fragments of GK1.5, which did not deplete CD4 $+T$ cells, and in athymic mice. These findings indicate that, in response to a single intratracheal antigen challenge, recruitment to the lungs of leukocytes other than CD8 $+T$ cells depends largely on CD4 $+T$ cells, possibly because of signals requiring $\mathrm{T}$ cell activation via interactions with antigen-presenting cells. (J. Clin. Invest. 1991. 88:1244-1254.) Key words: cell ablation - flow cytometry - histology • lung diseases • sheep erythrocytes
\end{abstract}

\section{Introduction}

Helper T cells appear to be crucial both for defense of the lung against specific pathogens and in the development of immunologic lung diseases. Helper $T$ cells are required for the differentiation of antigen-activated precursor lymphocytes (both B cells and cytotoxic $T$ cells) into immune effectors. Moreover, helper $T$ cells secrete cytokines that activate macrophages, endothelial cells, and other pulmonary cells to express adhesion molecules, to elaborate chemotactic and proinflammatory cytokines, and to present antigens, all of which are pivotal steps in the development of protective immune responses (1). Helper T

Results of these experiments were reported in part at the 50th Annual Meeting of the American Federation for Clinical Research (1990. Clin. Res. 38:438A).

Dr. Curtis's current address is Pulmonary \& Critical Care Medicine Section (111G), Department of Veterans Affairs Medical Center, 2105 Fuller Road, Ann Arbor, MI 48105.

Address reprint requests to Dr. Kaltreider, Respiratory Care Section (111D), San Francisco VA Medical Center, 4150 Clement Street, San Francisco, CA 94121-1598.

Received for publication 25 June 1990 and in revised form 19 June 1991.

The Journal of Clinical Investigation, Inc.

Volume 88, October 1991, 1244-1254 cells are the predominant lymphocytes in the lungs of patients with sarcoidosis and are prominent in idiopathic pulmonary fibrosis $(2,3)$. Considerable evidence, both from clinical and experimental research, suggests that helper $T$ cells are essential components of the deranged immune responses that appear to underlie these important lung diseases $(4,5)$.

Helper $\mathrm{T}$ lymphocytes can be identified by surface expression of the CD4 molecule (in mice also termed L3T4), a transmembrane glycoprotein of roughly $55-\mathrm{kD}$ relative mass, expressed on thymocytes and helper T cells of all mammals (6). Monoclonal antibodies (MAbs) against CD4 block T cell activation in vitro and when used in vivo have profound immunosuppressive effects $(7,8)$. Systemic therapy with MAbs against CD4 has recently been used in the treatment of rheumatoid arthritis $(9,10)$; whether such therapy would be useful in immunologic lung diseases or would impair development of protective immune responses is unknown.

The generation of immune responses in the lung parenchyma is believed to depend heavily on recruitment of lymphocytes, in particular from regional lymph nodes (11). Lymphocyte recruitment is a multistep process involving adhesion to and transmigration of endothelial cells, penetration of the vascular basement membrane, directed migration through extracellular matrix, and selective retention (12). Each of these steps in cellular accumulation has been extensively studied in vitro; however, the significance of findings from these studies to the pathogenesis of immunologic lung diseases remains undefined. It is critical for an understanding of pulmonary host defense that events within the lung parenchyma be studied directly, because immunologic diseases within the lung parenchyma are poorly reflected by changes in the organized systemic lymphoid tissue (a process termed compartmentalization [13]).

This laboratory is performing an ongoing series of in vivo studies to determine the cellular and molecular mechanisms underlying pulmonary immune responses. We have used sheep red blood cells as a particulate, $T$ cell-dependent antigen which mimics a variety of organic antigens that could be inhaled or aspirated into the lower respiratory tract. These studies have demonstrated that intratracheal antigen challenge of previously primed mice with sheep red blood cells results in immune activation of alveolar macrophages (as evidenced by increased expression of class II major histocompatibility antigens and ability to present antigen in vitro and in vivo); recruitment of large numbers of lymphocytes and monocytes, and smaller numbers of neutrophils to the lung parenchyma; and in situ maturation of recruited B cells to specific antigen-secreting cells (14-19). These changes require intratracheal challenge with specific antigen, and cannot be elicited by intratracheal inoculation of a nonspecific irritant (such as hydrochloric acid) or even of an unrelated erythrocyte antigen, suggesting a requirement for local antigen-driven signals. During this pulmonary immune response, CD4-positive $(+) \mathrm{T}$ cells appear in bronchoalveolar lavage fluid earlier and in greater numbers than do other lymphocyte subsets (18). Based on this observa- 
tion, and the known capability of CD4+ T cells to secrete the chemotactic cytokine interleukin 2 (IL-2), we hypothesized that, in this experimental model, CD4 $+\mathrm{T}$ cells participate in the recruitment of other lymphocyte subsets to the lungs. To explore the role of CD4+ T cells in vivo, we studied the consequences of systemic treatment of mice with GK1.5, a rat MAb directed against murine CD4. Two complementary experimental designs were used: systemic depletion of CD4+ T cells by injection of intact GK1.5 and surface blockade of the CD4 molecule by $F\left(a b^{\prime}\right)_{2}$ fragments of GK1.5. We found that, with both designs, recruitment of inflammatory cells to the alveolar spaces and lung parenchyma in response to intratracheal antigen challenge was profoundly inhibited.

\section{Methods}

Animals. Most experiments were performed using specific pathogenfree female C57BL/6 mice obtained at 8-10 wk of age from Jackson Laboratories, Bar Harbor, ME, or Simonsen Laboratories, Gilroy, CA. Athymic male C57BL/6 $\times$ BALB/c F1 (B6/CBy F1) nu/nu mice and their normal littermates, obtained at $5 \mathrm{wk}$ of age from Jackson Laboratories, were used in selected experiments. Athymic BALB/c $n u / n u$ mice, obtained at 5-6 wk of age from Simonsen Laboratories, were used to produce large quantities of monoclonal antibodies. All mice were housed in the San Francisco VA Medical Center Animal Care Facility, which is fully accredited by the American Association for Accreditation of Laboratory Animal Care. C57BL/6 mice were fed standard animal laboratory diet (Rodent Lab Chow No. 5001, Ralston Purina Co., St. Louis, MO) and chlorinated tap water ad lib. Athymic mice were housed in isolette cages and were fed autoclaved chow and sterile chlorinated water ad lib. C57BL/6 mice were used at 10-16 wk of age; B6/CBy F1 nu/nu mice and their normal littermates were used within $4 \mathrm{wk}$ of arrival. BALB/c athymic mice were used within $3 \mathrm{mo}$ of arrival.

Purification of monoclonal antibodies. The hybridomas listed in Table I were obtained from the American Type Culture Collection, Rockville, MD, and were grown in ascites in pristane-primed BALB/c $n u / n u$ mice (20). Ascites was centrifuged at $1,500 \mathrm{~g}$ to remove red blood cells, ultracentrifuged at $13,000 \mathrm{~g}$ to remove lipids, and then partially purified by addition of an equal volume of saturated ammonium sulfate solution. After dialysis against phosphate-buffered saline (PBS, pH 7.2), the resulting IgG fraction was used for ablation experiments or to prepare $\mathrm{F}\left(\mathrm{ab}^{\prime}\right)_{2}$ fragments (below). In ablation experiments, the dose of antibody was calculated as the product of the total protein concentration (determined by optical density at $280 \mathrm{~nm}$ ) and the percentage of MAb (determined by cellulose acetate electrophoresis under nonreducing conditions). For use as a staining reagent for immunofluorescence analysis by flow cytometry, this ammonium sulfate fraction was further purified by elution from immunoaffinity columns (Zymed Labs, Inc., S. San Francisco, CA) as directed by the manufacturer, and then coupled either to fluorescein isothiocyanate (FITC) (21) or to biotin (22) (both obtained from Sigma Chemical Co., St. Louis, MO).

Table I. MAbs Used

\begin{tabular}{lll}
\hline \multicolumn{1}{c}{ Hybridoma } & \multicolumn{1}{c}{ Isotype } & \multicolumn{1}{c}{ Antigen } \\
\hline GK1.5 & rat IgG2b & murine CD4 \\
SFR8-B6 & rat IgG2b & HLA-Bw6 (irrelevant antibody) \\
MAR 18.5 & mouse IgG2a & rat Ig kappa chain \\
53-6.72 & rat IgG2a & murine CD8 \\
RA3-3A1 & rat IgM & murine B220 (pan B cell) \\
M1/9.3.4.HL.2 & rat IgG2a & murine CD45 (leukocyte \\
& & common antigen)
\end{tabular}

Preparation of $F\left(a b^{\prime}\right)_{2}$ antibody fragments. $\mathrm{F}\left(\mathrm{ab}^{\prime}\right)_{2}$ fragments were prepared by pepsin digestion (23). The purity of the resulting preparation was tested in three ways: by sodium dodecyl sulfate (SDS)-polyacrylamide gel electrophoresis (PAGE) run under reducing conditions and developed by Coomassie Blue (24), by the ability of fragments to block binding of intact antibody to appropriate control lymphocytes in vitro as determined by flow cytometry (see Results); and by absence of depletion of CD4+ T cells in vivo (see Results).

Antigens and immunizations. Sheep red blood cells (sheep no. 602) (Colorado Serum Co., Boulder, CO) were washed three times in $7 \mathrm{ml}$ of normal saline before use. C57BL/6 or B6/CBy F1 mice were immunized (primed) by intraperitoneal (IP) injection of $1 \times 10^{8}$ sheep red blood cells in $0.5 \mathrm{ml}$ of saline. 14-21 d later, primed mice were used in experimental protocols. Sheep red blood cells are not mitogenic for $\mathrm{T}$ cells in vitro (25) and do not directly induce immune activation of alveolar macrophages (as detected by increased expression of Ia antigen) in the naive mouse (17). Thus, it is likely that sheep red blood cells function solely as an antigen in this model system.

Experimental protocols. To establish the duration of CD4+ ablation induced by intact GK1.5, in initial experiments primed mice were injected intraperitoneally with $2 \mathrm{mg}$ of antibody on day -4 or -5 and again with $1 \mathrm{mg}$ on day -2 . Mice were then bled on various days (without intratracheal challenge or additional antibody injections). Lymphocytes were purified from peripheral blood by centrifugation through Lympholyte-M (Cedarlane Laboratories, Hornby, Ontario) and their phenotypes were determined by flow cytometry.

In subsequent studies with intact antibodies, primed mice were injected with either GK1.5 or the irrelevant control antibody (SFR8-B6) following this same protocol. An additional group of mice, referred to subsequently as the untreated group, did not receive antibody. On day 0 , all mice next received an intratracheal antigen challenge $\left(5 \times 10^{8}\right.$ sheep red blood cells in $0.05 \mathrm{ml}$ of saline) as previously described (14). This technique causes the majority of the antigen to be deposited and retained in the alveolar spaces (26) and results in a reproducible pulmonary immune response (16-19). This antigen dose, which is higher than that used in most of our previously reported studies, was chosen because it induces more vigorous cellular recruitment to the lungs (16). At various times after challenge, mice were deeply anesthetized with pentobarbital and killed by exsanguination. We have previously shown that the peak response to the standard treatment was at 3-4 d after IT immunization and that the response declines thereafter (19). Mice next underwent a 12-ml total lung lavage with PBS in 1-ml aliquots as previously described (17). After recovery of the last aliquot of lavage fluid, the lungs were inflated with $10 \%$ formalin in PBS (vol/vol) at a constant pressure (19) and were submitted for histologic analysis.

$\mathrm{F}\left(\mathrm{ab}^{\prime}\right)_{2}$ fragments usually have a much shorter span of circulation than do intact antibodies. Therefore, several different protocols were used in $\mathrm{F}\left(\mathrm{ab}^{\prime}\right)_{2}$ antibody studies to determine how frequently fragments had to be injected into primed mice to reliably maintain blockade of CD4 molecules on T cells. Successful blockade of CD4 molecules without depletion of CD4 + T cells was demonstrated by flow cytometry by absence of staining with antibody against CD4 and by positive staining with antibody against rat Ig $\kappa$ chain. The final protocol used for the $\mathrm{F}\left(\mathrm{ab}^{\prime}\right)_{2}$ experiment involved injection of one $\mathrm{mg}$ of antibody daily on days $-5,-4$, and -2 , intratracheal challenge on day 0 , and injection of two $\mathrm{mg}$ of antibody daily on days $\mathbf{0 , 1}$, and 2 .

Quantitation of bronchoalveolar cells. For cell counts, bronchoalveolar lavage samples were processed individually and are expressed as cells per mouse. Total cell count was determined by hemocytometer, and differential cell counts were performed on slides prepared by the gravity filtration method (18) and stained by hematoxylin and eosin. We counted 200 cells per slide.

Procedure for flow cytometry. We identified lymphocyte subpopulations in bronchoalveolar lavages, peripheral blood, and spleen by staining cells with MAbs and analyzing them by flow cytometry. Lavages of individual mice were analyzed for the untreated group and for the group treated with the irrelevant antibody, but for the group treated with GK1.5 lavages of 8-14 mice were pooled to obtain sufficient cells. 
Cells were suspended at $2-4 \times 10^{7} \mathrm{ml}^{-1}$ in minimal essential medium (Cell Culture Facility, University of California, San Francisco) containing $\mathbf{0 . 1 \%}$ sodium azide (Mallinckrodt Chemicals, Inc., St. Louis, MO) and $25 \mathrm{mM}$ Hepes (Sigma Chemical Co.). Aliquots of $25 \mu \mathrm{l}$ were stained with $50 \mu \mathrm{l}$ of MAb at previously defined optimal dilutions in 96-well, round-bottomed plates (Linbro, Hamden, CT).

Flow cytometry was performed using a FACS 440 (Becton-Dickinson Immunocytometry Systems, Mountain View, CA), equipped with an argon laser (Coherent 90-6, emission wavelength of $488 \mathrm{~nm}$, operated at $200 \mathrm{~mW}$ ), a rhodamine-G dye laser (Coherent $90-4+599$, emission wavelength of $610 \mathrm{~nm}$, operated at $300 \mathrm{~mW}$ ), and a four-decade logarithmic amplifier. Data were stored in list mode on a VAX 11380 computer (Digital Equipment Corp., Maynard MA) and were analyzed using ELECTRIC DESK software (Becton-Dickinson). For each lavage sample we analyzed a minimum of 20,000 cells, excluding erythrocytes, dead cells, and debris by forward angle scatter gating before collecting data (27). In each experiment, these exclusions and the adequacy of compensation between the photomultiplier tubes for the two fluorochromes were confirmed by staining with FITC-conjugated antibody and biotinylated antibody against the common leukocyte antigen, T200 (murine CD45).

We identified lymphocytes among bronchoalveolar lavage cells by comparing their light scatter characteristics to those of splenic or peripheral blood lymphocytes analyzed in the same experiment (18). Flow cytometry data are expressed as absolute number of lymphocytes per mouse of each phenotypic subpopulation in lavage samples. We determined these numbers by the product of the total cell count (by hemocytometer), the percentage of lymphocytes (by differential cell counts of slides prepared by the gravity filtration method), and the percentage of each lymphocyte subpopulation (by flow cytometry).

The CD4 molecule has been reported on macrophages of humans and rats (28), but has not been found on resident peritoneal macrophages of mice (29-31). To our knowledge, alveolar macrophages of mice have not been examined for expression of CD4. Therefore, to exclude the possibility that effects on inflammatory cell influx could be due in part to an effect on alveolar macrophages, in separate experiments we examined bronchoalveolar lavages of mice that had not been injected with GK1.5 for CD4 staining by flow cytometry, using strepta-

\section{Table II. Histologic Grading Criteria}

\begin{tabular}{|c|c|}
\hline \\
\hline \multicolumn{2}{|c|}{$\begin{array}{l}\text { Alveolar wall intlammation } \\
1+\quad \text { Increased numbers of }\end{array}$} \\
\hline $2+$ & $\begin{array}{l}\text { As above, plus } 1-3 \text { foci per section showing cellular } \\
\text { alveolar exudate and atelectasis. }\end{array}$ \\
\hline $3+$ & $\begin{array}{l}\text { As above, plus more than } 3 \text { foci per section showing } \\
\text { cellular alveolar exudate and atelectasis. }\end{array}$ \\
\hline \multicolumn{2}{|c|}{ Perivenous regions } \\
\hline $1+$ & Occasional veins cuffed by inflammatory cells. \\
\hline $2+$ & $\begin{array}{l}\text { Most veins surrounded by a thin layer ( } 1-5 \text { cells thick) of } \\
\text { inflammatory cells. }\end{array}$ \\
\hline $3+$ & $\begin{array}{l}\text { Most veins surrounded by a thick layer ( }>5 \text { cells thick) of } \\
\text { inflammatory cells. }\end{array}$ \\
\hline \multicolumn{2}{|c|}{ Periarterial and peribronchial regions } \\
\hline \multirow{2}{*}{\multicolumn{2}{|c|}{$\begin{array}{l}\text { Same scoring crit } \\
\text { Venous endothelial changes }\end{array}$}} \\
\hline & \\
\hline $1+$ & $\begin{array}{l}\text { Scattered inflammatory cells adherent to the } \\
\text { endothelium; flat endothelial cells. }\end{array}$ \\
\hline $2+$ & $\begin{array}{l}\text { Endothelial cells show hypertrophy; } 1-3 \text { veins per section } \\
\text { show focal piling up of inflammatory cells along the } \\
\text { endothelium. }\end{array}$ \\
\hline & $\begin{array}{l}\text { Endothelial cells show hypertrophy; }>3 \text { veins per section } \\
\text { show piling up of inflammatory cells, usually marked. }\end{array}$ \\
\hline te & \\
\hline
\end{tabular}

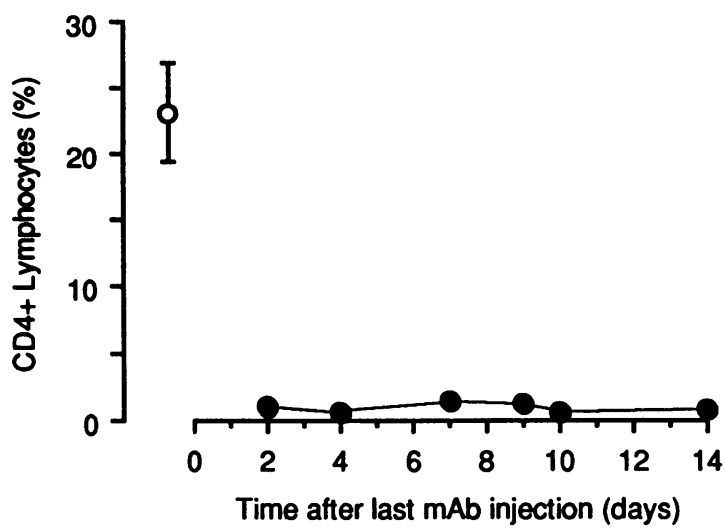

Figure 1. Kinetics of depletion of CD4+ T cells by intact GK1.5. Primed mice were injected intraperitoneally with intact GK1.5 (2 mg on day -2 and $1 \mathrm{mg}$ on day 0 ). Individual mice were then bled two to three times each over $2 \mathrm{wk}$ and the percentage of CD4+ T cells in peripheral blood was determined by flow cytometry. Data are mean \pm SEM; (๑) mice treated with GK1.5 ( $n=3-6$ mice assayed individually); (o) normal mice ( $n=14$ mice assayed individually).

vidin-allophycocyanin (Becton-Dickinson) to minimize the effect of macrophage autofluorescence (32).

Preparation and grading of histologic specimens. After inflation of the lungs with formalin, the entire thoracic contents were dissected and were fixed by immersion in 10\% formalin in PBS for 18-24 h. Parasagittal sections through the lungs were then cut, embedded in paraffin, and sectioned at $5 \mu \mathrm{m}$ in thickness. The slides, each consisting of the entire lungs from a single mouse, were stained with hematoxylin and eosin and in some cases with the Verhoeff-van Gieson stain for elastin. Slides were coded and were graded in a blinded fashion by one of the authors (Dr. Warnock), a pathologist specializing in pulmonary diseases, using a reproducible scoring system developed for use in this model (19). Inflammatory changes in five categories were graded separately on each slide: $(a)$ the alveolar parenchyma away from major vessels; $(b)$ the perivenular region; $(c)$ the bronchoarterial region; $(d)$ venous endothelial changes; and $(e)$ arterial endothelial changes. Grading was based on the most severely inflamed section on each slide. The specific grading criteria are summarized in Table II.

Statistical analysis. Data are expressed as mean \pm SEM. Continuous ratio scale data were evaluated by analysis of variance (ANOVA) with Newman-Keuls follow-up; discrete ordinal data were analyzed by the Mann-Whitney test (two samples) or the Kruskal-Wallis test (three samples) (33). Statistical calculations were performed on a Macintosh SE computer (Apple Computer, Inc., Cupertino, CA) using the program STATVIEW (BrainPower, Inc., Calabasas, CA). Statistical difference was accepted at $P<0.05$.

\section{Results}

Depletion of CD4+ $T$ cells by in vivo antibody treatment. The protocol of antibody injection that we employed reliably depleted CD4+ $\mathrm{T}$ cells from the peripheral blood of previously primed mice for a period of at least fourteen days (Fig. 1). In subsequent experiments using intratracheal antigen challenge, this protocol also resulted in systemic depletion of CD4+ T cells. $7 \mathrm{~d}$ after intratracheal antigen challenge of mice injected with GK1.5, spleens contained $1.25 \pm 0.29 \%$ CD4+ T cells, compared to $24.97 \pm 2.22 \%$ for normal mice $(n=12)$. In both sets of experiments, no staining was detected by flow cytometry using MAR 18.5, a MAb against rat Ig $\kappa$ chain, which would have reacted with the $\kappa$ chain of GK1.5 if it were present on 


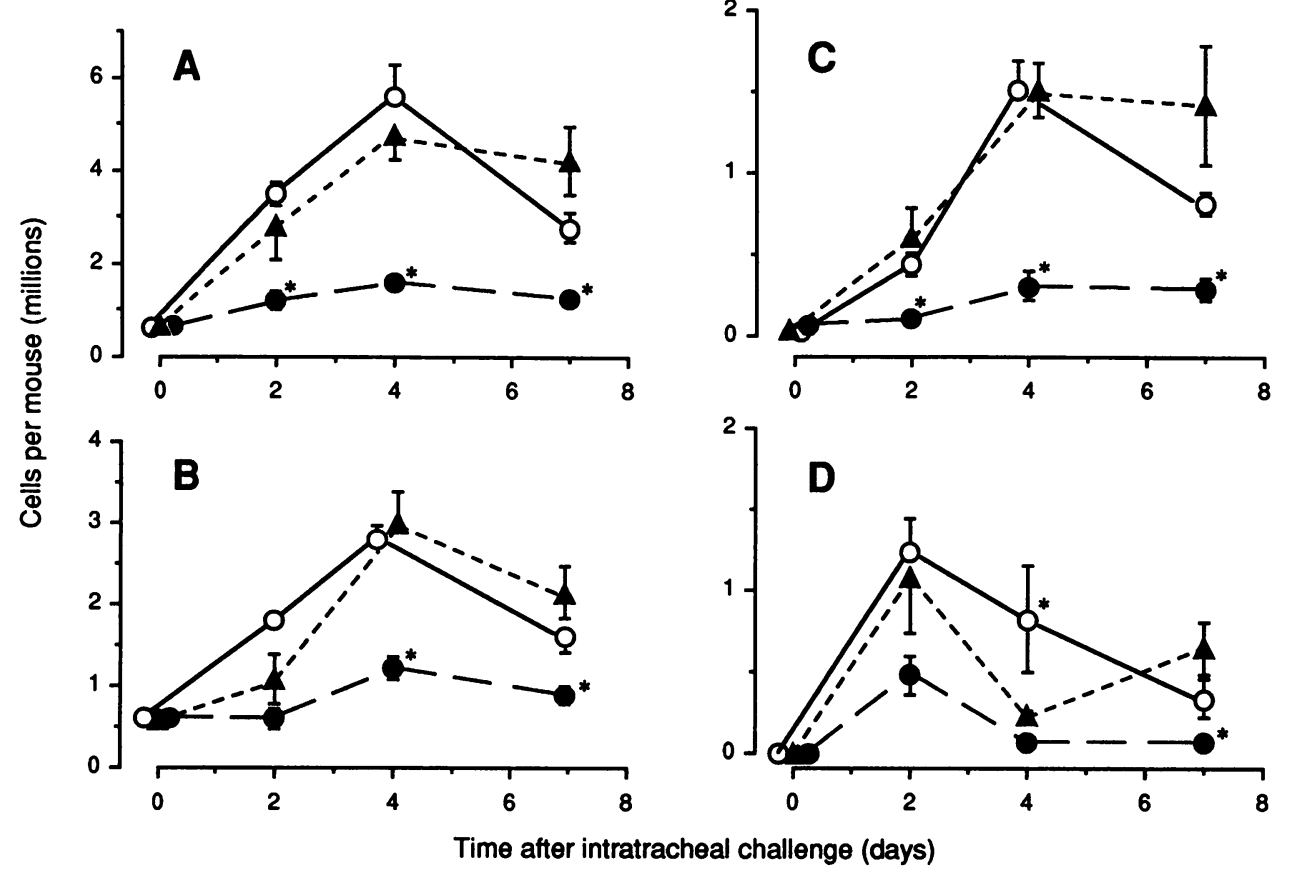

Figure 2. Analysis of bronchoalveolar lavage fluid of mice treated with intact antibody. The lungs of primed mice treated with GK1.5(๑), SFR8B6 (0), or no antibody ( $\Delta$ ) were lavaged on various days after intratracheal challenge. Bronchoalveolar lavage fluid was analyzed for total cell counts by hemocytometer and for differential cell count by the gravity filtration method. $(A)$ Total cell count; $(B)$ macrophages; $(C)$ lymphocytes; $(D)$ neutrophils. Each point represents the mean \pm SEM of 4-10 mice assayed individually; *significant difference, $P<0.05$, compared to other groups by ANOVA with Newman-Keuls followup. Note the difference in scales. lymphocytes. This absence of staining confirms that CD4+ T cells had been ablated; their CD4 molecules had not simply been masked by GK1.5.

Effect of treatment with intact GK1.5 on recruitment of inflammatory cells into the lungs. As anticipated from previous work with this model $(16,18)$, intratracheal challenge of systemically primed mice caused an increase in the number of leukocytes in bronchoalveolar lavages, due to increases in all leukocyte subtypes (Fig. 2). Similar results were seen in mice treated with the irrelevant antibody. In contrast, treatment with GK1.5 markedly inhibited recruitment of total bronchoalveolar inflammatory cells at all time points after intratracheal challenge. Compared to both control groups, significant decreases were seen in numbers of macrophages and lymphocytes in mice treated with GK1.5.

Flow cytometric analysis of bronchoalveolar lavage fluid seven days after intratracheal challenge showed that mice treated with intact GK1.5 had total absence of CD4+ T cells and had significant decreases of $B$ cells compared to mice treated with the isotype-control antibody or no antibody (Fig. 3). Simultaneous analysis of the spleens and peripheral blood of mice treated with intact GK1.5 demonstrated that systemic depletion of $\mathrm{CD} 4+\mathrm{T}$ cells was complete.

However, numbers of $\mathrm{CD} 8+\mathrm{T}$ cells recovered from the bronchoalveolar spaces were not affected by CD4 depletion. These results $\left(1.5 \pm 0.7 \times 10^{5} \mathrm{CD} 8+\mathrm{T}\right.$ cells per mouse in the GK1.5-treated group) indicated significant recruitment of $\mathrm{CD} 8+\mathrm{T}$ cells in response to intratracheal antigen challenge, compared to results of bronchoalveolar lavage fluid in three relevant control groups: normal mice, which we have previously reported to have $4 \pm 3 \times 10^{3} \mathrm{CD} 8+\mathrm{T}$ cells per mouse (18); primed mice treated with GK 1.5 by the same protocol but not intratracheally challenged with antigen $\left(6.36 \pm 2.04 \times 10^{3}\right.$ CD8 $+\mathrm{T}$ cells per mouse; $n=8-12$ mice pooled in each of two experiments); or primed mice treated with GK 1.5 by the same protocol but intratracheally challenged with saline $7 \mathrm{~d}$ earlier
(5.60 $\pm 3.05 \times 10^{3} \mathrm{CD} 8+\mathrm{T}$ cells per mouse; $n=8-12$ mice pooled in each of two experiments).

Histologic sections of the lungs of intratracheally challenged mice revealed a pronounced decrease in parenchymal inflammation in mice treated with GK1.5 (Fig. 4). The mice that received no antibody as well as those treated with the irrelevant antibody developed alveolar wall congestion, extensive perivenous and periarterial cuffing with a chiefly mononuclear cell infiltrate, and adhesion of inflammatory cells to vascular endothelium. These histologic changes were identical to those previously described in this model (19). In marked contrast,

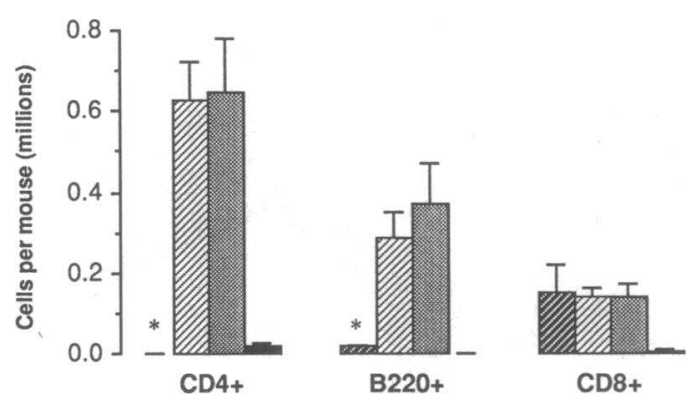

Figure 3. Flow cytometric analysis of bronchoalveolar lymphocytes. The lungs of primed mice treated with GK1.5 (dark cross-hatching), SFR8-B6 (light cross hatching), or no antibody (stippled) were lavaged $7 \mathrm{~d}$ after intratracheal challenge with sheep red blood cells. As an additional control, the lungs of primed mice treated with GK1.5 were lavaged $7 \mathrm{~d}$ after a sham challenge with saline (black bars). Data are mean \pm SEM of at least 5 mice individually assayed in each of two separate experiments (for no antibody and SFR8-B6-treated groups) and of 8-14 mice pooled in each of three separate experiments (for GK1.5-treated mice challenged with sheep red blood cells) or each of two separate experiments (for GK1.5-treated mice challenged with saline); *significant difference, $P<0.05$, compared to the two other groups challenged with sheep red blood cells by ANOVA with Newman-Keuls follow-up. 


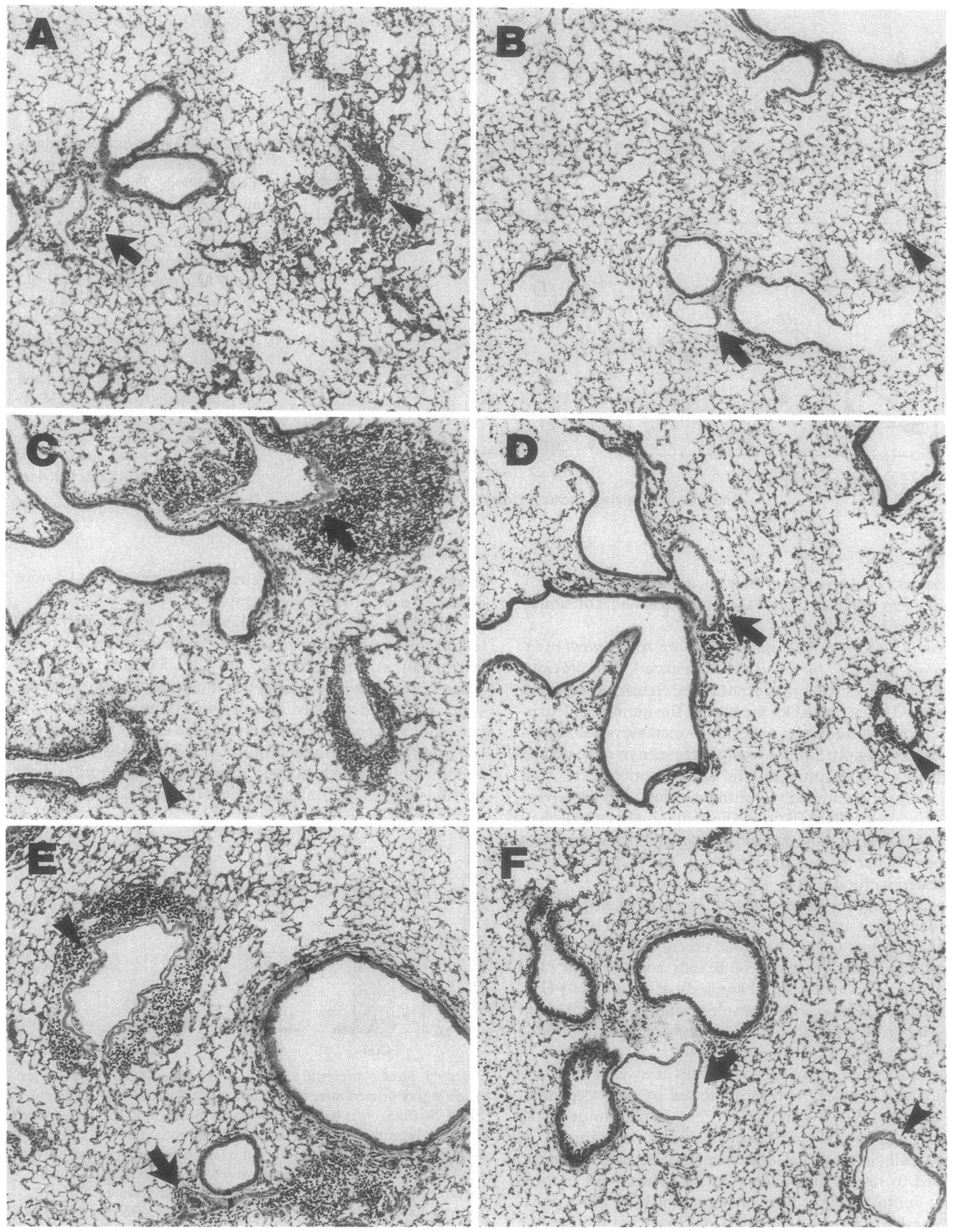

Figure 4. Representative photomicrographs of lungs of mice treated with intact antibody. Primed mice treated with SFR8-B6 $(A, C, E)$ or GK1.5 $(B, D, F)$ at $2 \mathrm{~d}(A$ and $B), 4 \mathrm{~d}(C$ and $D)$, or $7 \mathrm{~d}(E$ and $F)$ after intratracheal challenge. $(A)$ Moderate infiltrate of inflammatory cells around artery (arrow) and vein (arrowhead); endothelial cells are hypertrophied in the vein and small collections of cells are present subendothelially. Patchy increased cellularity of alveolar walls. (B) Minimal infiltrate of inflammatory cells around artery (arrow) and vein (arrowhead); parenchymal infiltrate is absent. $(C)$ Heavy infiltrate of inflammatory cells around artery and veins; vascular endothelial cells are hypertrophied in 

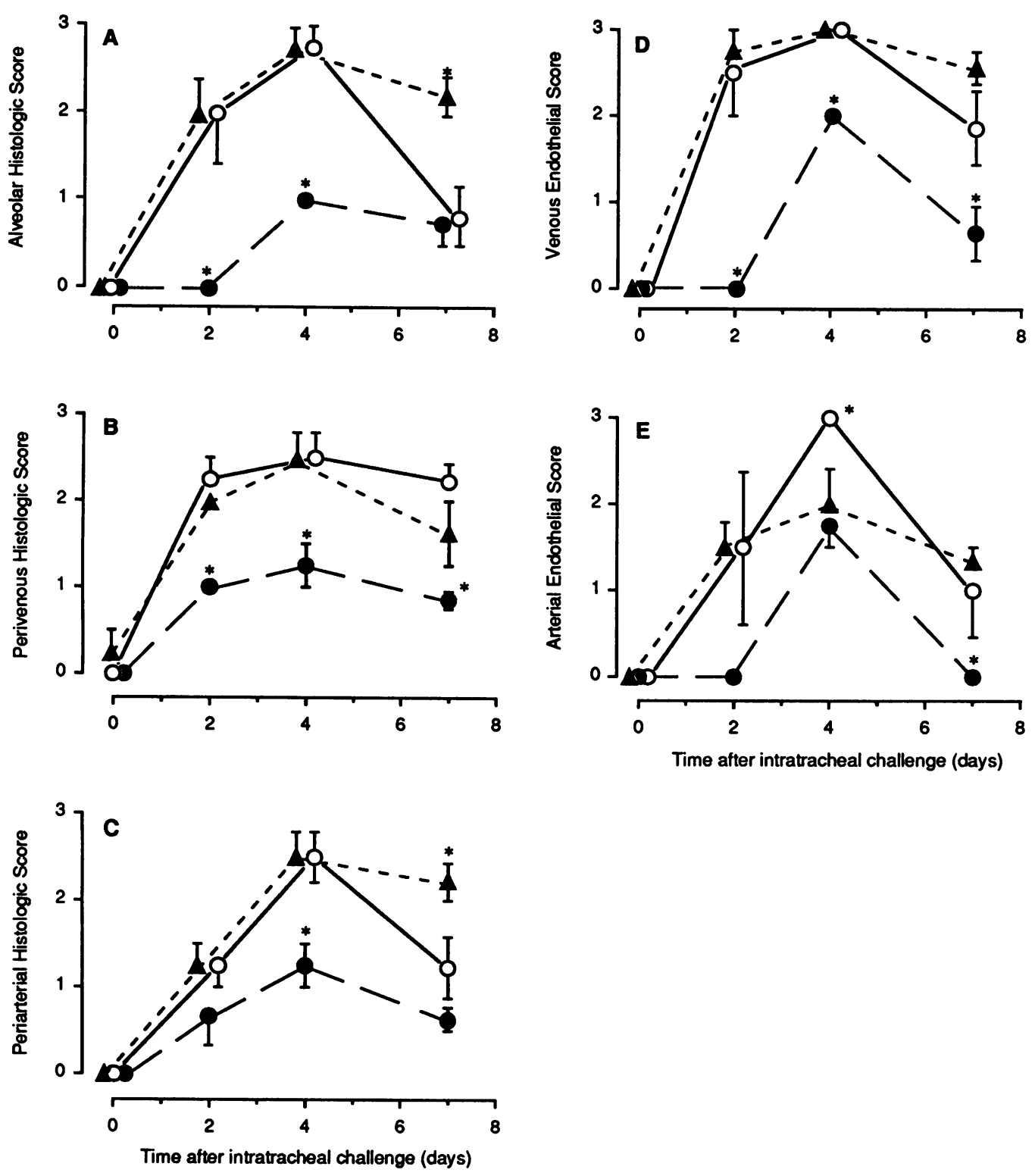

Figure 5. Histologic scores of mice treated with intact antibody. Lungs were prepared for histologic section various days after intratracheal challenge of primed mice. Sections were scored blindly using the criteria listed in Table II. $(A)$ Alveolar score; $(B)$ perivenous score; $(C)$ periarterial score; $(D)$ venous endothelial score; $(E)$ arterial endothelial score. Symbols: (ム) untreated group; (O) SFR8B6-treated group; (๑) GK1.5treated group. Each point represents the mean \pm SEM of 4-10 mice; *significant difference, $P<0.05$, compared to other groups by KruskalWallis test with a NewmanKeuls-like follow-up.

parenchymal inflammation was considerably less well developed and less uniform in mice treated with GK1.5. Many areas of lung of mice treated with GK1.5 appeared essentially normal. The histologic scoring of specific aspects of inflammation (Fig. 5) showed that GK1.5 treatment decreased those scores which reflect parenchymal inflammation (alveolar, perivenous, and periarterial scores) and attachment of leukocytes (which are primarily mononuclear cells) to venous endothelium. Treatment with intact GK1.5 had less of an effect, however, on the attachment of leukocytes (which are chiefly neutrophils) to arterial endothelial cells.

Absence of CD4 from murine alveolar macrophages. Alveolar macrophages from mice that had not received injections of
GK1.5 showed negligible CD4 staining when analyzed by flow cytometry using allophycocyanin. In normal mice, alveolar macrophages were $1.4 \% \mathrm{CD} 4+(n=9$ mice, pooled lavage), whereas in primed mice $7 \mathrm{~d}$ after intratracheal antigen challenge, alveolar macrophages were $1.08 \pm 0.29 \%$ CD4+ (mean \pm SE, $n=4$ mice individually assayed).

Effect of treatment with $F\left(a b^{\prime}\right)_{2}$ fragments of $G K 1.5$ on inflammatory cell recruitment to the lungs. Injection of $\mathrm{F}\left(\mathrm{ab}^{\prime}\right)_{2}$ fragments of GK1.5 blocked CD4 molecules on lymphocytes of primed mice, as shown by absent staining with GK1.5-FITC and staining with MAR 18.5-FITC (Fig. 6). In mice treated with $\mathrm{F}\left(\mathrm{ab}^{\prime}\right)_{2}$ fragments of GK1.5, CD4 $+=0.06 \pm 0.02 \%$ in blood, $0.04 \pm 0.01$ in spleen; MAR-18.5+ $=19.3 \pm 1.7 \%$ in

artery and veins. One vein has subendothelial collections of inflammatory cells (arrowhead); no parenchymal infiltrate. (D) Mild perivascular infiltrate of inflammatory cells around artery and vein; no parenchymal infiltrate. $(E)$ Moderate perivascular infiltrate; endothelial cells are flat; mild parenchymal infiltrate. $(F)$ Minimal perivascular infiltrate; endothelium is flat; no parenchymal infiltrate. Hematoxylin and eosin stain; all magnifications are $\times 56$. 

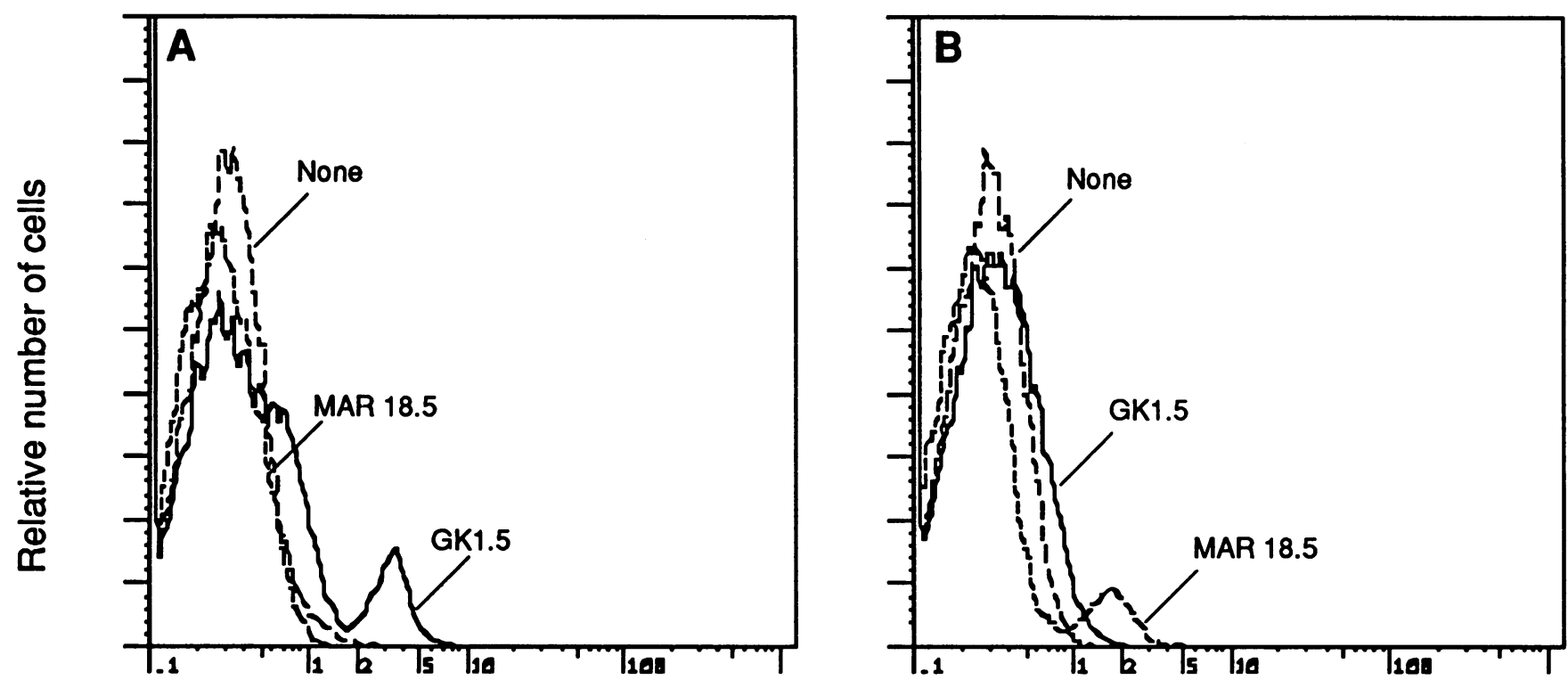

\section{Fluorescence (arbitrary units)}

Figure 6. Blockade of CD4 by $\mathrm{F}\left(\mathrm{ab}^{\prime}\right)_{2}$ fragments of GK1.5. Peripheral blood lymphocytes of primed mice were stained with indicated MAbs and were analyzed by flow cytometry. Representative histograms, gated on lymphocytes, are shown from two individual mice. Data are relative number of cells (vertical axis) vs. log fluorescence intensity (horizontal axis). $(A)$ Untreated primed mouse has many CD4+ (GK1.5+) cells and no staining with antibody against rat Ig $\alpha$ chain (MAR 18.5). (B) Primed mouse treated with $F\left(a b^{\prime}\right)_{2}$ fragments of GK1.5 has no detectable CD4+ $(\mathrm{GK} 1.5+)$ cells but does have staining with antibody against rat Ig kappa chain (MAR 18.5).

blood, $19.3 \pm 1.5 \%$ in spleen. Just as was seen with intact antibody, treatment with $\mathrm{F}\left(\mathrm{ab}^{\prime}\right)_{2}$ fragments of GK1.5 significantly decreased recovery of total cells and of macrophages and lymphocytes by bronchoalveolar lavage (Fig. 7).

Analysis of histologic sections of mice treated with $\mathrm{F}\left(\mathrm{ab}^{\prime}\right)_{2}$ fragments gave results similar to those of the intact antibody experiments (Fig. 8). This experiment was performed on day 3 after intratracheal challenge and the resulting histologic scores were intermediate between the results of intact antibody stud-
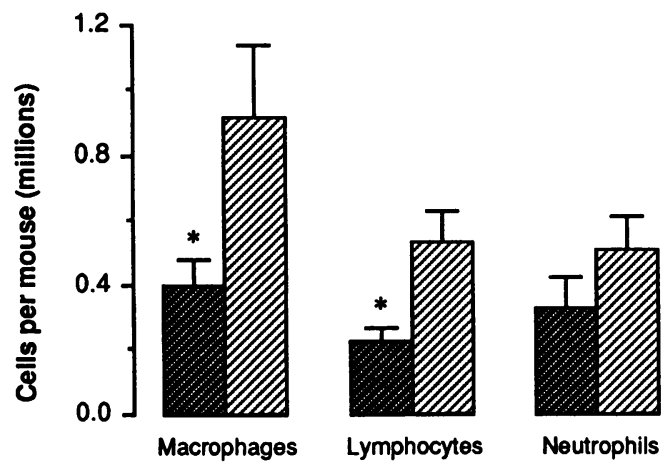

Figure 7. Phenotypes of bronchoalveolar leukocytes in mice treated with $\mathrm{F}\left(\mathrm{ab}^{\prime}\right)_{2}$ fragments. Primed mice were lavaged $3 \mathrm{~d}$ after intratracheal challenge and numbers of bronchoalveolar cells were determined by hemocytometer count and differential cell count. Darkly shaded bars: GK1.5-treated group; lightly shaded bars: SFR8-B6treated group. Each bar represents the mean \pm SEM of five mice; *significant difference, $P<0.05$, compared to other groups by ANOVA with Newman-Keuls follow-up. ies performed on days 2 and 4 after intratracheal challenge (Fig. 5).

To determine whether treatment caused persistent effects on CD4+ $T$ cells, in a separate experiment we stopped administration of $F\left(a b^{\prime}\right)_{2}$ fragments of GK1.5 the day of intratracheal antigen challenge and assayed mice $4 \mathrm{~d}$ later. Flow cytometric analysis of the peripheral blood of these mice showed that

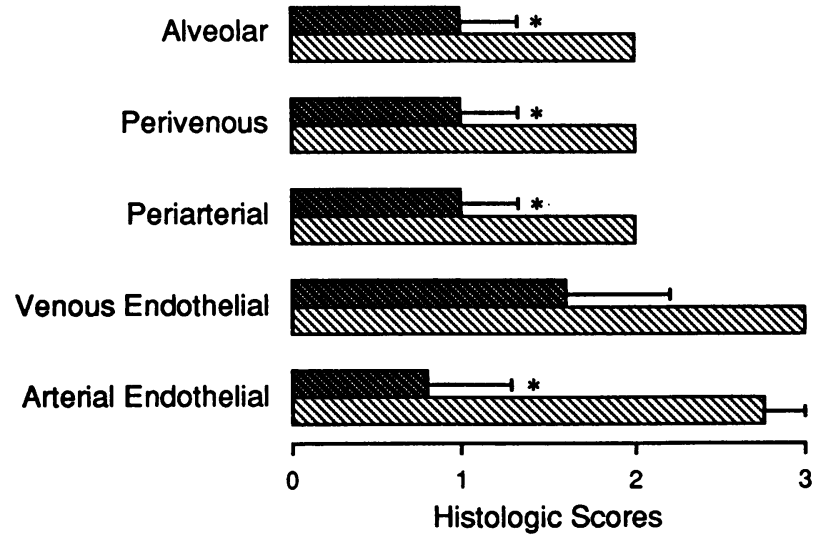

Figure 8. Histologic scores of mice treated with $\mathrm{F}\left(\mathrm{ab}^{\prime}\right)_{2}$ fragments. Lungs were prepared for histologic section three days after intratracheal challenge of primed mice treated with $\mathrm{F}\left(\mathrm{ab}^{\prime}\right)_{2}$ fragments of GK1.5 or SFR8-B6. Sections were scored blindly using the criteria listed in Table II. Darkly shaded bars: GK1.5-treated group; lightly shaded bars: SFR8-B6-treated group. Each bar represents the mean \pm SEM of five mice; *significant difference, $P<0.05$, by MannWhitney test. 
CD4+ $\mathrm{T}$ cells were again detectable without GK1.5 blockade. Analysis both of bronchoalveolar lavage and of histology showed a vigorous pulmonary immune response, indistinguishable from that in the untreated group (data not shown).

Pulmonary immune response in athymic mice. Because these results suggested that functional CD4 $+T$ cells are essential for the pulmonary immune response to sheep red blood cells, we predicted that inflammatory and immune cells would not be recruited to the lungs of athymic mice, which lack mature $\mathrm{T}$ cells. Results of both bronchoalveolar lavage cell yields and histologic scoring (Fig. 9) confirmed this prediction. Aside from erythrocyte-packed alveolar macrophages, lungs of athymic mice appeared essentially normal, in marked contrast to their normal littermates.

\section{Discussion}

These results show that when CD4+ T cells are depleted (by intact antibody) or rendered nonfunctional (by blockade of the CD4 molecule with $\mathrm{F}\left(\mathrm{ab}^{\prime}\right)_{2}$ antibody fragments), recruitment of immune and inflammatory cells to the lungs in response to intratracheal antigen is drastically impaired. Our results have important implications for the understanding of immunologic

A

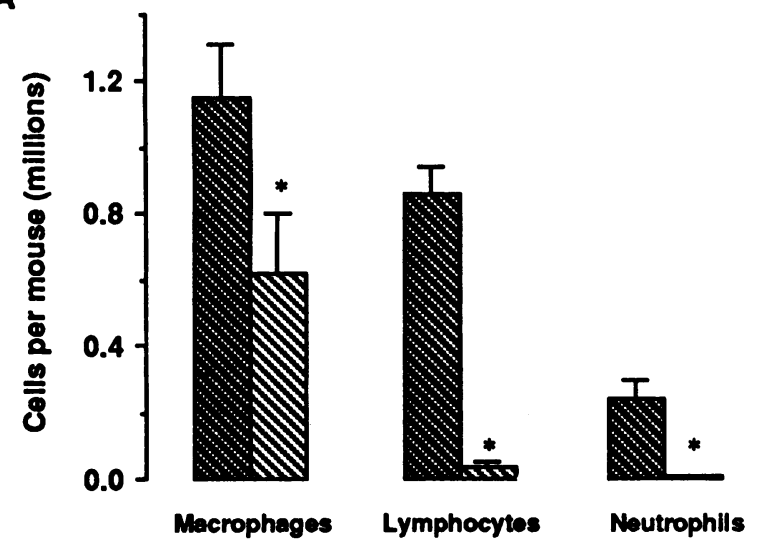

B

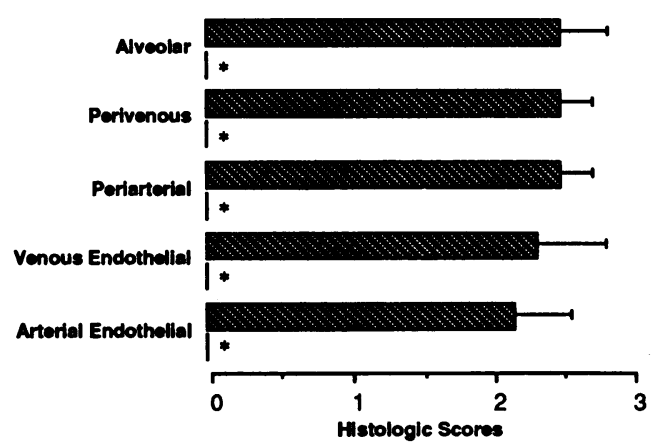

Figure 9. Absence of pulmonary immune response to intratracheal antigen in athymic mice. Primed B6/CBy F1 nu/+ mice (dark cross-hatching) or $n u / n u$ (athymic) mice (light cross-hatching) were challenged intratracheally with sheep red blood cells. $7 \mathrm{~d}$ later, lungs were lavaged to obtain bronchoalveolar cell counts $(A)$ and then inflated with formalin and processed for histologic scoring $(B)$. Each bar represents the mean \pm SEM of six mice assayed individually in two separate experiments; *significant difference, $P<0.05$, by MannWhitney test. lung diseases and of host defense of the lung, highlighting the critical role of the specific (i.e., antigen-driven) immune response and in particular of CD4 + T cells, in amplifying inflammatory effector mechanisms.

The end-points used in this study (analysis of cell numbers and phenotypes in bronchoalveolar lavage fluid and of histology) were chosen because they give complementary views of the inflammatory process. Analysis of bronchoalveolar lavage cells examines the entire alveolar surface in an integrated, quantitative fashion. In previous experiments in this model, we have noted excellent agreement between lymphocyte phenotypes in bronchoalveolar lavage fluid and in minced lungs following exhaustive lavage (18). We have interpreted this agreement to indicate that lymphocytes in the alveolar space are representative of those in the interstitium, the major site of the immune response. On the other hand, histologic analysis permits a detailed assessment of the sequence of changes at specific anatomic locations. We have previously shown that these endpoints are reasonable markers for production of specific antibody-forming cells in the lung. To our knowledge, the effect of depleting CD4+ $\mathrm{T}$ cells on cellular recruitment during a pulmonary immune response has been examined only by Allen et al. (34), who studied murine influenza. Interestingly, they found that depleting CD4+ T cells had little effect on cellular recruitment and no effect on clearance of virus in this class I MHC-restricted system. Although Mody et al. (35) demonstrated decreased survival and increased organism burden in CD4-depleted mice experimentally infected with Cryptococcus neoformans, they did not investigate the effect of treatment on cellular recruitment to the lungs.

Our results are best interpreted in light of our previous observations in this model system. Intratracheal deposition of sheep red blood cells into a naive mouse induces a prompt primary immune response in the draining mediastinal lymph nodes, even at relatively low doses of antigen, but minimal response in the lung parenchyma, unless extremely high doses of antigen are used $(16,18,19)$. Thus, the normal lung has a tremendous capacity to clear antigen without permitting a parenchymal immune response. In contrast, the immune mouse rapidly recruits large numbers of inflammatory and immune cells to the lung parenchyma and alveolar spaces in response to intratracheal antigen (18). The current study is part of an ongoing effort to define the cellular basis for this recruitment. One of our early hypotheses was that lymphocyte recruitment in the immune mouse results from monokines released as macrophages ingest opsonized antigen. This hypothesis predicts that ablation of CD4 + T cells would prevent maturation of B cells into specific antibody-forming cells, but would have little impact on their initial recruitment. However, the current data show that in the absence of CD4+ T cells, antigen alone is not sufficient to recruit $B$ cells or monocytes to the lungs, despite the presence of receptors for antigen or for immune complexes on these cell types. Interestingly, numbers of CD8+ T cells were not decreased by CD4 depletion, indicating that recruitment of this lymphocyte subset does not depend on CD4+ T cells.

Our data are compatible with two interpretations (not mutually exclusive) regarding the signals for recruitment of inflammatory cells in this model: first, that these signals are produced directly by CD4+ T cells; and second, that these signals derive from other cells which are themselves dependent on signals from CD4+ T cells. Inflammatory cell recruitment is a multi- 
factorial process that depends on display and recognition of adhesion molecules on both the leukocyte and the endothelial cell, directed migration along chemotactic gradients, and transmigration across the endothelium, basement membrane, and interstitium $(12,36,37)$. It is likely that $C D 4+T$ cells modulate multiple aspects of this process by secretion of lymphokines. For example, CD4+ T cells secrete IL-2, which is chemotactic for lymphocytes (38), and interferon- $\gamma$ (IFN- $\gamma$ ), which increases adhesiveness of endothelial cells for lymphocytes (39) and induces MECA 325, an endothelial vascular addressin associated with efficient lymphocyte transmigration of endothelia (40). Lymphocytes are also potent secretors of IL-8, a longacting chemotactic factor for neutrophils and lymphocytes (41, 42). All of these T cell-produced cytokines could directly contribute to cellular recruitment in this model. Alternatively, CD4+ $\mathrm{T}$ cells may indirectly stimulate inflammatory cell recruitment by activating multiple cell types to secrete proinflammatory cytokines such as IL-1, tumor necrosis factor- $\alpha$ (TNF- $\alpha),{ }^{1}$ IL-6, and IL-8 $(43,44)$. For instance, secretion of TNF- $\alpha$ by macrophages is increased by T cell-derived IFN- $\gamma$ (45). It is presently unclear which cytokines are most important for cellular recruitment in this model. IFN- $\gamma$ alone may be insufficient for cellular recruitment to the lungs, based on the experience with acute aerosol administration of that cytokine in rats (46). Our preliminary data suggest that blockade of TNF- $\alpha$ activity, by systemic treatment with a polyclonal antibody, does not block cellular recruitment in this model (J. L. Curtis, H. J. Fuchs, and D. Liggitt, unpublished observation) as it does in acute immune complex alveolitis in the rat (47). We suspect that both direct and indirect actions of CD4+ T cells contribute to cellular recruitment to the lungs in our model.

Administration of intact GK1.5 in vivo is believed to deplete CD4+ T cells via Fc receptor-mediated clearance during passage through the liver and spleen. Treatment with intact GK 1.5 has been used by a variety of investigators who have demonstrated delay or prevention of spontaneous autoimmune diseases (48-50), prolonged depression of humoral immune responses $(51,52)$, and delayed allograft rejection (53). Depletion of CD4+ T cells also worsens the clinical course in some (35) but not all infectious disease models (54-56). Improved outcome seen in CD4-depleted mice with experimental leishmaniasis has been taken as evidence for immunoregulatory subsets of CD4+ T cells which dampen the normal host response (57). Because in vivo treatment with antibody against CD4 induces immune tolerance, it is not complicated by development of a host response to the injected antibody, a common problem of in vivo treatment with other monoclonal antibodies (58).

In vivo treatment with $\mathrm{F}\left(\mathrm{ab}^{\prime}\right)_{2}$ fragments of $\mathrm{GK} 1.5$ appears to have similar immunosuppressive effects as treatment with intact antibodies, without depleting CD4+ T cells (23). AntiCD4 $\mathrm{F}\left(\mathrm{ab}^{\prime}\right)_{2}$ fragments are believed to be immunosuppressive in part because they inhibit the binding of CD4+ cells to antigen-presenting cells (59). The CD4 molecule interacts with nonpolymorphic determinants of class II MHC antigens on antigen-presenting cells, functioning both as an adhesion molecule and as co-receptor which is capable, through its association with the tyrosine-protein kinase $\mathrm{p} 56^{\text {lck }}$, of transducing an activation signal to the helper $T$ cell $(60,61)$. Therefore, the

1. Abbreviation used in this paper: TNF, tumor necrosis factor. effect of $F\left(a b^{\prime}\right)_{2}$ fragments of GK1.5 on inflammatory cell recruitment in this study suggests that the generation of recruitment signals requires an interaction with antigen-presenting cells.

Two other possible actions of $F\left(a^{\prime}\right)_{2}$ treatment should be considered. First, it has previously been shown that cross-linking certain CD4 determinants in vitro in the absence of accessory cells inhibits subsequent activation of the $T$ cell (62). Because they are bivalent, $F\left(a b^{\prime}\right)_{2}$ fragments of GK1.5 might cross-link CD4 and thus render T cells unresponsive to stimulation by antigen. However, the prompt recovery of the pulmonary immune response that we observed when treatment with $\mathrm{F}\left(\mathrm{ab}^{\prime}\right)_{2}$ fragments of GK1.5 was stopped argues that if such an action exists in vivo, the effect is not prolonged. Second, by blocking the CD4 molecule, $\mathrm{F}\left(\mathrm{ab}^{\prime}\right)_{2}$ treatment might also impede the action of lymphocyte chemotactic factor, which uses CD4 as its receptor (63). Lymphocyte chemotactic factor is a small molecular weight peptide, produced exclusively by CD8 + $\mathrm{T}$ cells, which is selectively chemoattractant for CD4+ $\mathrm{T}$ cells in vitro (12). Whether CD8 $+\mathrm{T}$ cells are themselves critical for cellular recruitment to the lungs is currently being investigated.

A theoretic objection to our methods is that MAR 18.5 staining would not detect any CD4 + T cells which had capped their CD4 molecules in response to antibody treatment, thus evading elimination, but which somehow remained functional. However, the antibody used, GK1.5, is reported not to induce capping of CD4 molecules (7). Our data from the $\mathrm{F}\left(\mathrm{ab}^{\prime}\right)_{2}$ experiments support this contention, since this divalent reagent should have induced capping roughly as well as intact antibody. In fact, observed numbers of MAR 18.5 + cells in peripheral blood closely approximated the expected numbers of CD4+ $\mathrm{T}$ cells in normal mice. Thus, we believe that it is unlikely that GK 1.5 treatment induced appreciable capping of CD4.

Although we have focused on the profound inhibitory effect of antibody against CD4 in this experimental pulmonary immune response, it is also important to note that some response did occur in GK1.5-treated mice, suggesting a redundancy in the mechanisms of inflammatory cell recruitment. Adhesion of inflammatory cells, particularly neutrophils, to pulmonary arterial endothelial cells was minimally affected and early recovery of neutrophils by bronchoalveolar lavage was not ablated. These findings are consistent with the recently described role in neutrophil adhesion of ELAM-1, an endothelial cell molecule inducible by monokines such as TNF- $\alpha$ and IL-1 (64). The lack of effect of CD4 depletion on recruitment of CD8 + T cells is interesting, particularly in light of the CD8+ bronchoalveolar lymphocytosis which often accompanies human immunodeficiency virus (HIV) infection (65). Preserved recruitment of $\mathrm{CD} 8+\mathrm{T}$ cells to the lungs during CD4 depletion was also recently observed in a murine model of influenza (34). In a new model of Pneumocystis carinii pneumonia in CD4depleted mice (66), we have noted a striking CD8+ pulmonary lymphocytosis (67). All of these observations indicate that CD8 + $T$ cells do not depend on CD4+ $T$ cells for their recruitment to the lungs.

It is unlikely that the functional changes observed in this study resulted from the effects of GK1.5 on other cell types. Murine macrophages from sites outside the lung do not express CD4 (29-31). Additionally, we found that alveolar macrophages both of normal mice and of mice undergoing a vigorous 
pulmonary immune response did not express detectable CD4. Pulmonary dendritic cells, another cell type potentially important in pulmonary immune responses, do not express CD4 in either mice or humans (68). Thus, it is probable that the effects observed in this study were due to ablation or inactivation of CD4+ $\mathrm{T}$ cells.

We believe that this model will be useful in further deciphering the mechanisms of cellular recruitment to the lungs during pulmonary immune responses. Our results indicate that one mechanism by which substantial reductions in the number or function of CD4+ T cells, as is seen in HIV infection, lead to impairment of pulmonary immune responses is by drastically diminishing cellular recruitment. Our results also raise the possibility that treatment with monoclonal antibodies against CD4 might be useful in patients with refractory immunologic pulmonary diseases such as sarcoidosis or idiopathic pulmonary fibrosis. In this regard, therapy with $F\left(a^{\prime}\right)_{2}$ fragments may be safer than therapy with intact antibody. The brief halflife of $F\left(a b^{\prime}\right)_{2}$ fragments would make treatment more difficult, but has the advantage of rapid reversal of immunosuppression in the event of complicating opportunistic infection. Finally, it is to be hoped that understanding the mechanisms regulating cellular recruitment to non-lymphoid organs will result in therapeutic agents more practical than monoclonal antibodies. If such agents are discovered, the lung provides a particularly attractive organ for their use, because of the possibility of lungspecific delivery by aerosol.

\section{Acknowledgments}

The authors thank Sheila Arraj, Janette Rullamas, and Danielle Doyle for technical assistance; Delene Johnson and Bill Hyun of the Laboratory for Cell Analysis, University of California, San Francisco, for assistance in flow cytometric analysis; George Gan for preparing the histologic sections; Drs. James M. Beck, Thomas H. Ermak, Nancy L. Gutstein, Jack Pappos, and Judd E. Shellito for helpful suggestions; and Dr. Beck for reviewing the manuscript.

This research was supported by research funds from the Department of Veterans Affairs, by the California Research Medical and Education Fund of the American Lung Association of California, and by National Institutes of Health grant HL-34298. Dr. Curtis is a recipient of a Research Associate Career Development Award from the Department of Veterans Affairs.

\section{References}

1. Curtis, J. L., and M. L. Warnock. 1991. New concepts in the pathogenesis of immune lung injury. Semin. Respir. Med. 12:158-176.

2. Hunninghake, G. W., and R. G. Crystal. 1981. Pulmonary sarcoidosis: a disorder mediated by excess helper T-lymphocyte activity at sites of disease activity. N. Engl. J. Med. 305:429-434.

3. Kradin, R. L., M. B. Divertie, R. B. Colvin, J. Ramirez, J. Ryu, H. A. Carpenter, and A. K. Bhan. 1986. Usual interstitial pneumonitis is a T-cell alveolitis. Clin. Immunol. Immunopathol. 40:224-235.

4. Hunninghake, G. W., G. N. Bedell, D. C. Zavala, M. Monick, and M. Brady. 1983. Role of interleukin-2 release by lung $T$-cells in active pulmonary sarcoidosis. Am. Rev. Respir. Dis. 128:634-638.

5. Saltini, C., J. R. Spurzem, J. J. Lee, P. Pinkston, and R. G. Crystal. 1986. Spontaneous release of interleukin 2 by lung $T$ lymphocytes in active pulmonary sarcoidosis is primarily from the Leu3+DR+T cell subset. J. Clin. Invest. 77:1962-70.

6. Bierer, B. E., B. P. Sleckman, S. E. Ratnofsky, and S. J. Burakoff. 1989. The biologic roles of CD2, CD4, and CD8 in T-cell activation. Annu. Rev. Immunol. 7:579-599.

7. Seaman, W. E., and D. Wofsy. 1988. Selective manipulation of the immune response in vivo by monoclonal antibodies. Annu. Rev. Med. 39:231-41.

8. Waldmann, H. 1989. Manipulation of T-cell responses with monoclonal antibodies. Annu. Rev. Immunol. 7:407-444.
9. Herzog, C., C. Walker, W. Müller, G. Riethmuller, W. Muller, and W. J. Pichler. 1989. Anti-CD4 antibody treatment of patients with rheumatoid arthritis. I. Effect on clinical course and circulating T cells. J. Autoimmun. 2:643-649.

10. Burmester, G. R., G. Horneff, F. Emmrich, and J. R. Kalden. 1990. Treatment of rheumatoid arthritis with an anti-CD4 monoclonal antibody. Clin. Res. 38:317A. (Abstr.)

11. Bice, D. E., and G. M. Shopp. 1988. Antibody responses after lung immunization. Exp. Lung Res. 14:133-156.

12. Berman, J. S., D. J. Beer, A. C. Theodore, H. Kornfeld, J. Bernardo, and D. M. Center. 1990. Lymphocyte recruitment to the lung. Am. Rev. Respir. Dis. 142:238-257.

13. Saltini, C., M. E. Hemler, and R. G. Crystal. 1988. T lymphocytes compartmentalized on the lower respiratory tract express the very late activation antigen complex VLA-1. Clin. Immunol. Immunopathol. 46:221-233.

14. Kaltreider, H. B., J. L. Caldwell, and P. K. Byrd. 1986. The capacity of normal murine alveolar macrophages to function as antigen-presenting cells for the initiation of primary antibody-forming cell responses to sheep erythrocytes in vitro. Am. Rev. Respir. Dis. 133:1097-1104.

15. Michael, P. F., and H. B. Kaltreider. 1986. The effect of phagocytosis by alveolar macrophages on the induction of antibody-forming cells in regional lymph nodes of inbred mice in response to intratracheally administered sheep erythrocytes. Clin. Res. 34:693A. (Abstr.)

16. Kaltreider, H. B., J. L. Curtis, and S. M. Arraj. 1987. The mechanism of appearance of specific antibody-forming cells in lungs of inbred mice after intratracheal immunization with sheep erythrocytes. II. Dose-dependence and kinetics of appearance of antibody-forming cells in hilar lymph nodes and lungs of unprimed and primed mice. Am. Rev. Respir. Dis. 135:87-92.

17. Kaltreider, H. B., P. K. Byrd, and J. L. Curtis. 1988. Expression of Ia by murine alveolar macrophages is up-regulated during the evolution of a specific immune response in pulmonary parenchyma. Am. Rev. Respir. Dis. 137:14111416.

18. Curtis, J. L., and H. B. Kaltreider. 1989. Characterization of bronchoalveolar lymphocytes during a specific antibody-forming cell response in the lungs of mice. Am. Rev. Respir. Dis. 139:393-400.

19. Curtis, J. L., M. L. Warnock, S. M. Arraj, and H. B. Kaltreider. 1990. Histologic analysis of an immune response in the lung parenchyma of mice: angiopathy accompanies inflammatory cell influx. Am. J. Pathol. 137:689-699.

20. Hoogenraad, N., T. Helman, and J. Hoogenraad. 1983. The effect of pre-injection of mice with pristane on ascites tumour formation and monoclonal antibody production. J. Immunol. Methods. 61:317-320.

21. Mishell, B. B., and S. M. Shiigi. 1980. Selected Methods in Cellular Immunology. W. H. Freeman \& Co., San Francisco. 292 pp.

22. Goding, J. W. 1976. Conjugation of antibodies with fluorochromes: modifications to the standard methods. J. Immunol. Methods. 13:215-226.

23. Gutstein, N. L., and D. Wofsy. 1986. Administration of $F\left(a^{\prime}\right)_{2}$ fragments of monoclonal antibody to L3T4 inhibits humoral immunity in mice without depleting L3T4+ cells. J. Immunol. 137:3414-3419.

24. Laemmli, U. K. 1970. Cleavage of structural proteins during the assembly of the head of bacteriophage T4. Nature (Lond.). 227:680-685.

25. Malynn, B. A., and H. H. Wortis. 1984. Role of antigen-specific B cells in the induction of SRBC-specific T cell proliferation. J. Immunol. 132:2253-2258.

26. McLeod, E., J. Caldwell, and H. B. Kaltreider. 1978. Pulmonary immune responses of inbred mice: appearance of antibody-forming cells in C57BL/6 mice after intrapulmonary or systemic immunization with sheep erythrocytes. Am. Rev. Respir. Dis. 118:561-571.

27. Parks, D. R., and L. A. Herzenberg. 1984. Fluorescence-activated cell sorting: theory, experimental optimization and applications in lymphoid cell biology. Methods Enzymol. 108:197-233.

28. Wood, G. S., N. L. Warner, and R. A. Warnke. 1983. Anti-Leu-3/T4 antibodies react with cells of monocyte/macrophage and Langerhans lineage. $J$. Immunol. 131:212-216.

29. Jefferies, W. A. J. R. Green, and A. F. Williams. 1985. Authentic T helper CD4 (W3/25) antigen on rat peritoneal macrophages. J. Exp. Med. 162:117-127. 30. Stewart, S. J., J. Fujimoto, and R. J. Levy. 1986. Human T lymphocytes and monocytes bear the same Leu-3 (T4) antigen. J. Immunol. 136:3773-3778.

31. Crocker, P. R., W. A. Jefferies, S. J. Clark, L. P. Chung, and S. Gordon. 1987. Species heterogeneity in macrophage expression of the CD4 antigen. $J$. Exp. Med. 166:613-618.

32. Fuchs, H. J., J. McDowell, and J. E. Shellito. 1988. Use of allophycocyanin allows quantitative description by flow cytometry of alveolar macrophage surface antigens present in low numbers of cells. Am. Rev. Respir. Dis. 138:1124 8.

33. Zar, J. H. 1974. Biostatistical Analysis. Prentice-Hall, Inc., Englewood Cliffs, NJ. 718 pp.

34. Allen, W., Z. Tabi, A. Cleary, and P. C. Doherty. 1990. Cellular events in the lymph node and lung of mice with influenza: consequences of depleting CD4+ T cells. J. Immunol. 144:3980-3986.

35. Mody, C. H., M. F. Lipscomb, N. E. Street, and G. B. Toews. 1990. Depletion of CD4+ (L3T4+) lymphocytes in vivo impairs murine host defense to Cryptococcus neoformans. J. Immunol. 144:1472-1477. 
36. Pober, J. S. 1988. Cytokine-mediated activation of vascular endothelium: physiology and pathology. Am. J. Pathol. 133:426-433.

37. Yednock, T. A., and S. D. Rosen. 1989. Lymphocyte homing. Adv. Immunol. 44:313-378.

38. Kornfeld, H., J. S. Berman, D. J. Beer, and D. M. Center. 1985. Induction of human T lymphocyte motility by interleukin 2. J. Immunol. 134:3887-3890.

39. Yu, C. L., D. O. Haskard, D. Cavender, and M. Ziff. 1985. Human gamma interferon increases the binding of $\mathrm{T}$ lymphocytes to endothelial cells. Clin. Exp. Immunol. 62:554-560.

40. Duijvestijn, A. M., A. B. Schreiber, and E. C. Butcher. 1986. Interferongamma regulates an antigen specific for endothelial cells involved in lymphocyte traffic. Proc. Natl. Acad. Sci. USA. 83:9114-9118.

41. Larsen, C. G., A. O. Anderson, E. Appella, J. J. Oppenheim, and K Matsushima. 1989. The neutrophil-activating protein (NAP-1) is also chemotactic for T lymphocytes. Science (Wash. DC). 243:1464-1466.

42. Baggiolini, M., A. Walz, and S. L. Kunkel. 1989. Neutrophil-activating peptide-1/interleukin 8 , a novel cytokine that activates neutrophils. J. Clin. In vest. 84:1045-1049.

43. Hunninghake, G. W., A. J. Glazier, M. M. Monick, and C. A. Dinarello. 1987. Interleukin-1 is a chemotactic factor for human T-lymphocytes. Am. Rev. Respir. Dis. 135:66-71.

44. Ming, W. J., L. Bersani, and A. Mantovani. 1987. Tumor necrosis factor is chemotactic for monocytes and polymorphonuclear leukocytes. J. Immunol. 138:1469-1474.

45. Collart, M. A., D. Belin, J. D. Vassalli, S. de Kossodo, and P. Vassailli. 1986. $\gamma$ Interferon enhances macrophage transcription of the tumor necrosis factor/cachectin, interleukin 1 , and urokinase genes which are controlled by short-lived repressors. J. Exp. Med. 164:2113-2118.

46. Debs, R. J., H. J. Fuchs, R. Philip, A. B. Montgomery, E. N. Brunette, D. Liggitt, J. S. Patton, and J. E. Shellito. 1988. Lung-specific delivery of cytokines induces sustained pulmonary and systemic immunomodulation in rats. J. Immunol. 140:3482-3488.

47. Warren, J. S., K. R. Yabroff, D. G. Remick, S. L. Kunkel, S. W. Chensue, R. G. Kunkel, K. J. Johnson, and P. A. Ward. 1989. Tumor necrosis factor participates in the pathogenesis of acute immune complex alveolitis in the rat. $J$. Clin. Invest. 84:1873-1882.

48. Ranges, G. E., S. Sriram, and S. M. Cooper. 1985. Prevention of type II collagen-induced arthritis by in vivo treatment with anti-L3T4. J. Exp. Med. 162:1105-1110.

49. Wofsy, D. 1986. Administration of monoclonal anti-T cell antibodies retards murine lupus in BXSB mice. J. Immunol. 136:4554-4560.

50. Wofsy, D., and W. E. Seaman. 1987. Reversal of advanced murine lupus in NZB/NZW F1 mice by treatment with monoclonal antibody to L3T4. $J$. Immunol. 138:3247-3253.

51. Goronzy, J., C. Y. Weyand, and C. G. Fathman. 1986. Long-term humoral unresponsiveness in vivo, induced by treatment of monoclonal antibody against L3T4. J. Exp. Med. 164:911-925.

52. Wofsy, D., D. C. Maues, J. Woodcock, and W. E. Seaman. 1985. Inhibition of humoral immunity in vivo by monoclonal antibody to L3T4: studies with soluble antigens with intact mice. J. Immunol. 135:1698-1701.

53. Woodcock, J., D. Wofsy, E. Erikson, J. H. Scott, and W. E. Seaman. 1986 Rejection of skin grafts and generation of cytotoxic $\mathrm{T}$ cell by mice depleted of L3T4 cells. Transplantation. 42:636-642.
54. Titus, R. G., R Ceredeg J. C Cerottini, and J. A. Louis. 1985. Therapeutic effect of anti-L3T4 monoclonal antibody GK1.5 on leishmaniasis in genetically susceptible BALB/c mice. J. Immunol. 135:2108-2114.

55. Grau, G. E., P. F. Piquet, H. D. Engers, J. A. Louis, P. Vassalli, and P. H Lambert. 1986. L3T4 positive T lymphocytes play a major role in the pathogenesis of murine cerebral malaria. J. Immunol. 137:2348-2354.

56. Sadick, M. D., F. P. Heinzel, V. K. Shigekane, W. L. Fisher, and R. M Locksley. 1987. Cellular and humoral immunity to Leishmania major in genetically susceptible mice after in vivo depletion of L3T4+ T cells. J. Immunol. 139:1303-1309.

57. Heinzel, F. P., M. D. Sadick, B. J. Holaday, R. L. Coffman, and R. M. Locksley. 1989. Reciprocal expression of interferon $\gamma$ or interleukin 4 during the resolution or progression of murine leishmaniasis: evidence for expansion of distinct helper T cell subsets. J. Exp. Med. 169:59-72.

58. Gutstein, N. L., W. E. Seaman, J. H. Scott, and D. Wofsy. 1986. Induction of immune tolerance by administration of monoclonal antibody to L3T4. $J$. Immunol. 137:1127-1132.

59. Wilde, D. B., P. Marrack, J. Kappler, D. Dialynas, and F. W. Fitch. 1983. Evidence implicating L3T4 in class II MHC antigen reactivity: monoclonal antibody GK1.5 (anti-L3T4) blocks class II MHC antigen-specific proliferation, release of lymphokines, and binding by cloned murine helper $\mathrm{T}$ lymphocyte lines. J. Immunol. 131:2178-2183.

60. Janeway, C. A. Jr., J. Rojo, K. Saizawa, U. Dianzani, P. Portoles, B. J. Jones, and S. Haque. 1989. The co-receptor function of murine CD4. Immunol. Rev. 109:77-92.

61. Veillette, A., M. A. Bookman, E. M. Horak, L. E. Samelson, and J. B. Bolen. 1989. Signal transduction through the CD4 receptor involves the activation of the internal membrane tyrosine-protein kinase $556^{\text {kt }}$. Nature (Lond.) 338:257-259.

62. Bank, I., and L. Chess. 1985. Perturbation of the T4 molecule transmits a negative signal to T cells. J. Exp. Med. 162:1294-1303.

63. Cruikshank, W. W., J. S. Berman, A. C. Theodore, J. Bernardo, and D. M. Center. 1987. Lymphokine activation of T4+ T lymphocytes and monocytes. $J$. Immunol. 138:3817-3823.

64. Bevilacqua, M. P., S. Spengeling, M. A. Gimbrone Jr., and B. Seed. 1989. Endothelial leukocyte adhesion molecule 1: an inducible receptor for neutrophils related to complement regulatory proteins and lectins. Science (Wash. DC). 243:1160-1165.

65. Itescu, S., L. J. Brancato, J. Buxbaum, P. K. Gregersen, C. C. Rizk, T. S. Croxson, G. E. Solomon, and R. Winchester. 1990. A diffuse infiltrative CD8 lymphocytosis syndrome in human immunodeficiency virus (HIV) infection: a host immune response associated with HLA-DR5. Ann. Intern. Med. 112:3-10.

66. Shellito, J., V. V. Suzara, W. Blumenfeld, J. M. Beck, H. J. Steger, and T. H. Ermak. 1990. A new model of Pneumocystis carinii infection in mice selectively depleted of helper T lymphocytes. J. Clin. Invest. 85:1686-1693.

67. Beck, J. M., M. J. Sniezek, S. M. Arraj-Peffer, J. L. Curtis, and J. E. Shellito. 1990. Cellular responses to Pneumocystis carinii pneumonia in a murine model. Am. Rev. Respir. Dis. 141:A530.

68. Sert, K., T. Takemura, E. Tshachler, V. J. Ferrans, M. A. Kaliner, and E. M. Shevach. 1986. Dendritic cells with antigen-presenting capability reside in airway epithelium, lung parenchyma and visceral pleura. J. Exp. Med. 163:436451. 